\title{
Eleutherine palmifolia (L.) Merr. Extract Increases the Crypts and Caspase-3 Expression in Colitis-Associated Colon Cancer Model
}

\author{
Roihatul Mutiah1, Wahyi Yucha Firsyaradha', Riza Ambar Sari', Rahmi Annisa', Risma Aprinda \\ Kristanti $^{2}$, Yen Yen Ari Indrawijaya ${ }^{1}$, Tias Pramesti Griana ${ }^{2}$, Anik Listiyana ${ }^{2 *}$
}

1. Department of Pharmacy, Maulana Malik Ibrahim State Islamic University, Malang, Jl. Gajayana No. 50 Malang Indonesia 65144

2. Department of Biomedic, Maulana Malik Ibrahim State Islamic University, Malang, Jl. Gajayana No. 50 Malang Indonesia 65144

\begin{tabular}{l}
\hline Info Article \\
\hline Submitted: 07-09-2020 \\
Revised: 07-10-2020 \\
Accepted: $15-12-2020$ \\
*Corresponding author \\
Anik Listiyana \\
Email: \\
Aniklis.biomed@gmail.com
\end{tabular}

Aniklis.biomed@gmail.com

\section{ABSTRACT}

It is known that Eleutherine palmifolia (L.) Merr contains flavonoid and polyphenol as bioactive compounds that have the ability as chemopreventive agents. This study aims to examine the effect of Eleutherine palmifolia (L.) Merr extract (EPE) on colon histopathology and the enhancement of caspase3 expression in BALB/c mice of colitis-associated colon cancer (CAC) model. Thirty Balb/c female mice were used in this study and were divided into six groups. Five mice in one group was normal or negative control (given phosphate-buffered saline), and twenty-five mice were induced intraperitoneally with $10 \mathrm{mg} / \mathrm{kg}$ BW AOM (Azoxymethane), and it was followed by the administration of 5\% DSS (Dextran Sodium Sulfate) every two weeks for 20 weeks. At sixth week, one mice in each group was sacrificed for Fecal Occult Bold Test (FOBT) and serum amyloid $\alpha$ (SAA) test to ensure that CAC was indeed formed. The administration of EPE with varying doses was started from eighth week and was continued until the $21^{\text {st }}$ week. The length of the colonic crypt was measured through histology appearance using Hematoxylin-eosin (HE) staining while the immunohistochemical method was used to observe apoptotic activity through the enhancement of caspase3 expression. The results showed that the increase in EPE dosage also increased the crypt colon length compared to the positive control group. The administration of $1.00 \mathrm{mg} / 20 \mathrm{gBW}$ EPE significantly increased cell apoptosis which can be observed through caspase-3 expression compared to the positive control group $(p<0.05)$. Based on these data, the extract of EPE can be developed as phytotherapy for chemopreventive.

Keywords: Eleutherine palmifolia extract, Colitis-Associated Colon Cancer, Colonic histopathology, Caspase-3

\section{INTRODUCTION}

Colorectal cancer originates from ileum tissue comprised of colon and rectum (Hildebrand, 2009). The cause of colorectal cancer is unknown, but chronic inflammatory diseases are one of the factors that can increase the occurrence of colorectal cancer. Ulcerative colitis (UC) is a condition with a chronic inflammatory appearance of the colon. The histological appearance is marked by mucosal damage and ulceration, which can lead to the ferocity of colon cancer (Kumar et al., 2010). Histological appearance of UC is divided into major and minor criteria. Major criteria show infiltration of inflammatory cells in the mucosa, crypt abscess, cryptitis, and villiform surface while the minor criteria show reduced goblet cells (Ariestine, 2008). The initial stages of colon cancer development are characterized by pathological changes in cryptic form and a decrease in the number of goblet cells in the colon (Kumar et al., 2013; Wicaksono \& Permana, 2013).

There is a mutation of the p53 gene in colon cancer, so p53 cannot bind to the sequences in DNA, and it causes the gene unable to induce apoptosis. The apoptosis mechanism is very complicated because it involves a series of biochemical signal transduction, and it is regulated by extrinsic and intrinsic ligands in a complex pathway. Apoptosis 
activation in either extrinsic or intrinsic pathways will lead to the activation of caspase-3 (Muhartono, 2017). The caspase- 3 expression is one of the markers for cell apoptosis activity. Activation of apoptosis through intrinsic or extrinsic pathways will lead to caspase-3 activation, where caspase-3 has a role as the main effector caspase in apoptosis process, and it can affect other caspases (Tamaki, 2003).

One of the development targets of anticancer drugs is apoptosis induction. The ability of a compound to trigger apoptosis to happen is very crucial because it means that new anticancer drugs can trigger apoptosis without endangering normal cells. One of the plants that have potential ability as an anticancer drug is Dayak onion (Eleutherine palmifolia (L.) Merr.). Dayak Onion contains naphthoquinone compound and its derivatives such as elecanacine, eleutherine, and eleuthernone. Naphthoquinone is a compound that has anticancer and antioxidant bioactivity (Kuntorini et al., 2016). Besides, Dayak onions are also known to contain many flavonoids (Sa'adah, 2017).

It was reported in previous studies that the Dayak onion fraction of ethyl acetate contains major compounds such as oxyresveratrol and isoliquiritigenin. Both of these compounds are assumed as lead compounds in anticancer activities (Minggarwati, 2017). Previous research shows that Dayak onion plants have the activities to inhibit the growth of Widr's colon cancer cells (Huwaida, 2017). Based on previous studies, it is known that dayak onions have the potential to help to cure cancer. Therefore, this study aims to scientifically prove the effect of giving Eleutherine palmifolia extract on colon histopathology and apoptosis induction through caspase-3 expression on an experimental animal of colitis-associated colon cancer model.

\section{MATERIAL AND METHODS Plant material}

This study used Eleutherine palmifolia bulbs, originated from Central Kalimantan Province, Indonesia. The identification and authenticity tests of the plants were conducted at Materia Medika Batu, East Java, Indonesia with number 074/348/102.7/2017. The identified specimen was stored in the Laboratory of Pharmacognosy of UIN Maulana Malik Ibrahim Malang.

\section{Plant extraction}

Dayak onion bulbs are dried for five days in an oven at $40^{\circ} \mathrm{C}$ and are mashed into powder. Dayak onion powder was macerated with
96\% ethanol for three days and then filtered. The filtrate was evaporated with a rotary evaporator until solid extract can be obtained.

\section{Mice}

This study used female mice as experimental animals with a BALB/c strain, aged 8-12 weeks and weighed 20-30 grams. Mice are divided into six groups, and each group consists of 5mice. The six groups are negative control, positive control, doxorubicin $0.052 \mathrm{mg} / 20 \mathrm{~g}$ BW, EPE $0.25 \mathrm{mg} / 20 \mathrm{~g}$ BW, EPE $0.50 \mathrm{mg} / 20 \mathrm{~g}$ BW and EPE $1.00 \mathrm{mg} / 20 \mathrm{~g}$ BW. All the mice are acclimatized for one week in a room exposed to direct sunlight with normal temperature and humidity. The lighting of the room is set to $12 \mathrm{~h}$ dark cycle and $12 \mathrm{~h}$ bright cycle. All the mice are given water and standard pellet of ad libitum. The regulation on the use of experimental animals and the code of ethics were obtained from the Ministry of Health Polytechnic Malang with registration number 027/KEPK-POLKESMA/2019.

\section{AOM and DSS induction for the CAC model}

The negative control group was not induced, otherwise positive control was induced without therapy administration. Five groups were induced with $10 \mathrm{mg} / \mathrm{kg}$ BW in $25 \mathrm{mg} / \mathrm{mL}$ AOM (Sigma Aldrich, UK) by intraperitoneal at firstly. Then it was followed by administration of 5\% DSS (MW = 15.000, Sigma Aldrich UK) per oral every day in the $1^{\text {st }}, 3^{\text {rd }}, 5^{\text {th }}, 7^{\text {th }}, 9^{\text {th }}, 11^{\text {th }}, 13^{\text {th }}, 15^{\text {th }}, 17^{\text {th }}, 19^{\text {th }}$ and $21^{\text {st }}$ week. The body weight of the mice was measured once every week. At the sixth week, FOBT and SAA tests were performed to one mice each group (Endharti et al., 2016). During the induction period, in the seventh week, the four groups (doxorubicin and EPE therapy) were given treatment dosage weekly until $21^{\text {st }}$ week. Administration of $0.5 \mathrm{ml}$ dose EPE therapy was given orally to the therapy group. The EPE doses are $0.25 \mathrm{mg} / 20 \mathrm{~g} \mathrm{BW}, 0.50 \mathrm{mg} / 20 \mathrm{~g} \mathrm{BW}$, and 1.00 $\mathrm{mg} / 20 \mathrm{~g}$ BW (Huwaida, 2017). While doxorubicin (10mg/5ml, Kalbe Farma) dose of $0.05 \mathrm{mg}$ was intraperitoneally given to the other therapy group. The design of the study is shown in Figure 1. At the end of the $21^{\text {st }}$ week, mice in all groups were sacrificed.

\section{HE Staining of colon tissue}

Preparations were made using the paraffin method with Hematoxylin-Eosin (HE) staining. The tissue was stained with Hematoxylin-eosin (HE) so that the cell appearance looked red on the 
cytoplasm and blue on the core. The results of HE staining were observed using a binocular light microscope to measure crypt length. The colon organ specimens were randomly observed at ten different visual fields using microscope with 100 times magnification. On every visual field crypt, length are calculated, and the mean of each aspect is made (Wicaksono \& Permana, 2013; Rizki et al., 2015).

\section{Caspase-3 immunohistochemistry}

Immunohistochemical staining is done using the technique of paraffin block fixation of neutral buffered formalin. Caspase-3 polyclonal antibody rabbit polyclonal anti-mouse caspase-3 (Dako Glostrup, Denmark) is used as primary antibody and anti-rabbit biotin-conjugated is used as secondary antibody (Dako Glostrup, Denmark). The expression of caspase-3 was seen microscopically by observing brownish staining because the anti-caspase- 3 antibody reaction is visualized by DAB chromogen (Sigma Aldrich, UK). The observation was performed using a light microscope (Olympus) at 10 visual fields with 400 times magnification. Caspase-3 expression was calculated in the cytoplasm of colon epithelial cells that showed a brownish color.

\section{Data analysis}

Statistical data analysis was performed using One Way ANOVA test $(\mathrm{p}<0.05)$, followed by the Tukey Post Hoc test to find out which groups have significant differences.

\section{RESULT AND DISCUSSION \\ AOM and DSS induction for the CAC model}

The CAC experimental mice model that was induced with AOM and DSS show a pathological condition indicated by their body weight loss. The mice body weight measurement is conducted once a week from the $1^{\text {st }}$ week until $20^{\text {th }}$ week. The statistical analysis showed significant differences $(p<0.05)$ in the negative control group and positive control group for the EPE $1.00 \mathrm{mg} / 20 \mathrm{~g}$ BW dose group and the doxorubicin $0.052 \mathrm{mg} / 20 \mathrm{~g}$ BW group. This result indicates that there is a significant difference in the AOM-DSS induced group and the group that received therapy.

The results of Serum Amyloid $\alpha$ (SAA) and Fecal Occult Blood Test (FOBT) measurements at $6^{\text {th }}$ week in the statistical analysis showed a significant difference between the AOM-DSS induction groups and the groups without the AOM-DSS induction (negative control group). The results of the SAA and FOBT measurements (Table I).

\section{The effect of AOM-DSS administration and EPE therapy on mice body weight}

The changes in mice body weight loss can be used as an initial indicator of the activity of carcinogenic compounds in the body of experimental animals.Also, changes in body weight can also be used to determine the activity of anticancer compounds in EPE. The average body weight of mice in each treatment group tends to change in each week (Figure 2). A research mentioned that anticancer activity could be determined from the changes in the body weight of mice during treatment (Bahmudah, 2008).

The increase in body weight of mice tends to be slow in all groups, except in the negative control group where the body weight gain of the mice was more visible on several weeks of measurement. Besides, the mean changes in body weight of mice in the negative control group in the last week were seen to be the highest compared to the average body weight of other treatment groups. Its shows that the administration of AOM and DSS affects the changes in mice body weight. The decrease in body weight of mice induced by carcinogens occurred as a result of the mice immune response to carcinogens that penetrated the body of the mice. Cell damage caused by carcinogens generates an inflammatory reaction, in which the inflammatory reaction causes an increase of thermogenous proinflammatory cytokines. Since the body's calorie needs are increased, cancer, fat, and carbohydrates are converted into heat or body heat, which causes a decrease in the bodyweight of mice (Roselyn, 2016).

\section{EPE increases the colonic crypt length of the BALB/c mice of the CAC model}

The induction of AOM and DSS causes a decrease in the colonic crypt length of CAC model mice (Table II). The results of statistical analysis showed that the colonic crypt length in the negative control group and positive controls had a significant difference $(\mathrm{p}<0.05)$. Meanwhile, the EPE group with a dose of $0.50 \mathrm{mg} / 20 \mathrm{gBW}$ and 1.00 $\mathrm{mg} / 20 \mathrm{gBW}$ had a significant difference compared to the positive control group. It shows that EPE has the potential effect of increasing colonic crypt length significantly. The induction of carcinogenic compounds such as AOM will cause changes in normal crypts to become microadenomas (Snider, 2016). 
Table I. Results of SAA and FOBT measurements of BALB/c mice for CACmodel. Each mice of all group were sacrificed to conduct serum amyloid $\alpha$ and fecal occult blood test, which is performed four times. SAA samples were obtained from cardiac blood collection and analyze using ELISA assay, while FOBT samples were obtained by swab paper kit into rectum each mice. Calculation of total erythrocytes based on the number of cells erythrocytes that change color to green.

\begin{tabular}{|c|c|c|c|}
\hline \multirow{2}{*}{ The group } & \multirow{2}{*}{ SAA Concentration $(\mathrm{ng} / \mathrm{mL}) \pm \mathrm{SD}$} & \multicolumn{2}{|c|}{ Total erythrocytes of FOBT } \\
\hline & & Micro (cells) & Macro \\
\hline Control (-) & $107.30 \pm 2.60$ & $2 \pm 0.81$ & - \\
\hline Control (+) & $359.35 \pm 3.29 *$ & $39 \pm 2.16 *$ & + \\
\hline Doxorubicin $0.052 \mathrm{mg} / 20 \mathrm{~g} \mathrm{BW}$ & $348.59 \pm 1.67 *$ & $37 \pm 1.63 *$ & + \\
\hline EPE $0.25 \mathrm{mg} / 20 \mathrm{~g} \mathrm{BW}$ & $346.63 \pm 3.78 *$ & $32 \pm 1.71 *$ & + \\
\hline EPE $0.50 \mathrm{mg} / 20 \mathrm{~g} \mathrm{BW}$ & $330.75 \pm 4.22 *$ & $35 \pm 2.08 *$ & + \\
\hline EPE $1.00 \mathrm{mg} / 20 \mathrm{~g} \mathrm{BW}$ & $357.62 \pm 9.16 *$ & $42 \pm 1.71 *$ & + \\
\hline
\end{tabular}

${ }^{*} \mathrm{p}<0.01$ is significantly higher than the negative control group

Table II. Mean data of colonic crypt length in the BALB/c mice colon of the CAC model after treatment with EPE. Four mice of each group were sacrificed to conduct HE staining of colon tissue then observed using a microscope. The length of cryptic cells $(\mu \mathrm{m})$ were measure using Image Raster 3.0 software.

\begin{tabular}{cc}
\hline The group & Mean $(\boldsymbol{\mu m}) \pm$ SD \\
\hline Control (-) & $92.90 \pm 9.75^{*}$ \\
Control (+) & $51.80 \pm 6.25$ \\
Doxorubicin $0.052 \mathrm{mg} / 20 \mathrm{~g} \mathrm{BW}$ & $89.01 \pm 14.80$ \\
EPE $0.25 \mathrm{mg} / 20 \mathrm{~g} \mathrm{BW}$ & $79.59 \pm 22.93$ \\
EPE $0.50 \mathrm{mg} / 20 \mathrm{~g} \mathrm{BW}$ & $92.44 \pm 7.80^{*}$ \\
EPE $1.00 \mathrm{mg} / 20 \mathrm{~g} \mathrm{BW}$ & $93.71 \pm 31.39^{*}$ \\
\hline
\end{tabular}

${ }^{*} \mathrm{p}<0.05$ is significantly higher than positive control group

Table III. Mean data of caspase-3 expression in the BALB/c mice colon of the CAC model after treatment with EPE. Caspase-3 expression was observed using a light microscope and count the cytoplasm of colon epithelial cells that changes to brownish color.

\begin{tabular}{cc}
\hline The group & Mean (cells) \pm SD \\
\hline Control (-) & $42.82 \pm 13.47^{*}$ \\
Control (+) & $25.85 \pm 3.22^{*}$ \\
Doxorubicin $0.052 \mathrm{mg} / 20 \mathrm{~g} \mathrm{BW}$ & $24.07 \pm 8.02^{*}$ \\
EPE $0.25 \mathrm{mg} / 20 \mathrm{~g} \mathrm{BW}$ & $44.02 \pm 7.72$ \\
EPE $0.50 \mathrm{mg} / 20 \mathrm{~g} \mathrm{BW}$ & $45.50 \pm 6.36$ \\
EPE $1.00 \mathrm{mg} / 20 \mathrm{~g} \mathrm{BW}$ & $67.52 \pm 14.92$ \\
\hline
\end{tabular}

${ }^{*} \mathrm{p}<0.05$ is significantly lower than EPE $1.00 \mathrm{mg} / 20 \mathrm{~g}$ BW treatment group

Based on the histopathology picture of colonic cryptography in Figure 3.A, there is a difference in the morphology of colonic crypts, of a group, that have improved in the variations of the EPE dose administration compared to the positive control group. The positive control group appears to have the shortest crypt compared to other groups. Its caused by colitis occurred in the positive control group, which generates epithelial damage accompanied by infiltration of inflammatory cells in the mucosa that makes crypt becomes shorter (Erben et al., 2014). Crypt damage occurred in the colon is caused by the reduction of protein excretion associated with the tight junction. Thus, it increases colonic permeability and reduces barrier function (Jo et al., 2017). Histopathological features and graphs of colonic crypt mean length of BALB/c mice of colitis-associated colon cancer model (Figure 3). 


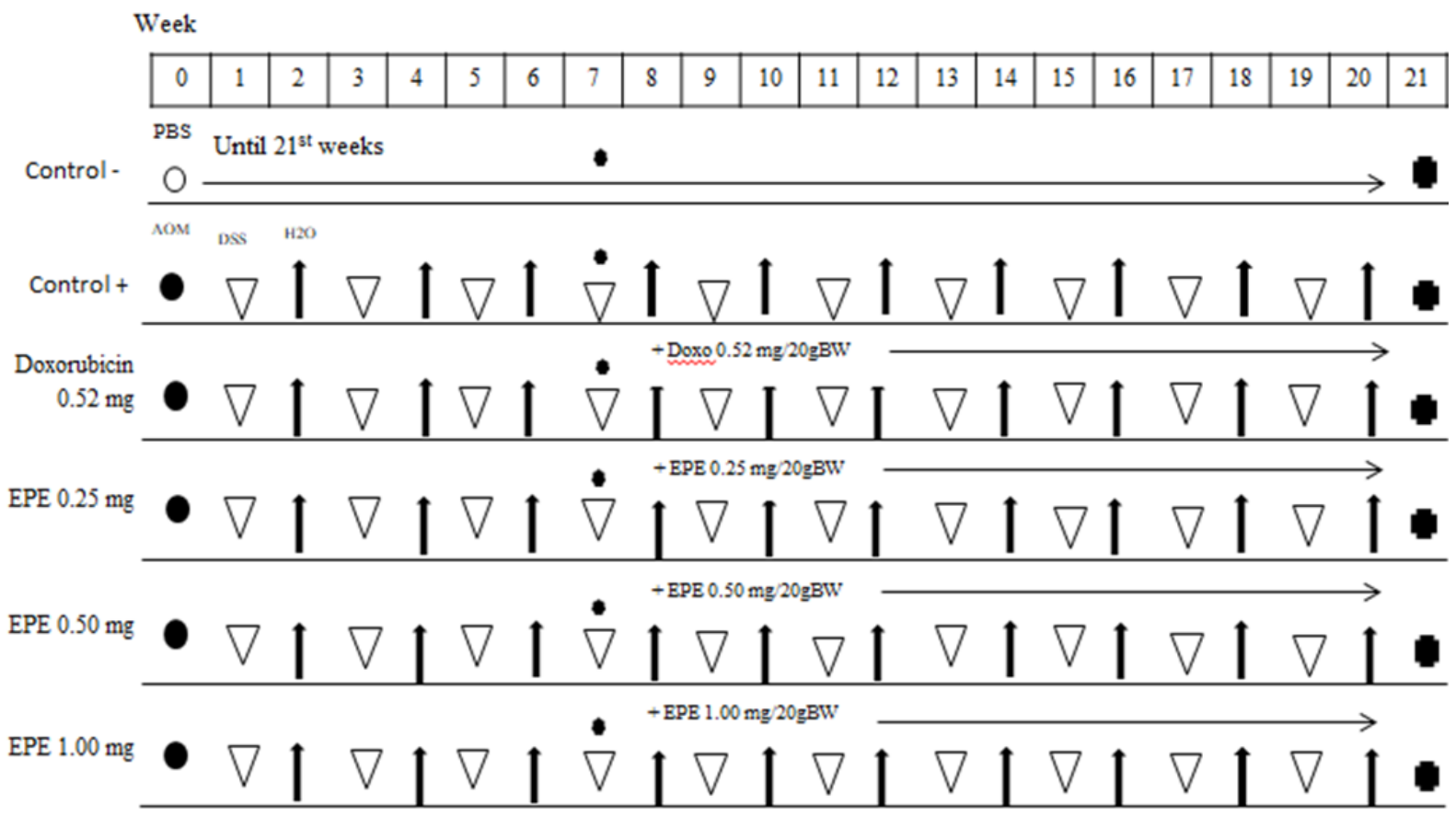

Figure 1. The experimental design of BALB/c mice of Colitis associated colon cancer model (CAC) and EPE therapy. $\mathrm{O}=\mathrm{PBS}, \boldsymbol{\theta}=\mathrm{AOM}, \nabla=\mathrm{DSS}, \boldsymbol{\top}=\mathrm{H} 2 \mathrm{O}, \quad=\mathrm{SAA} \& \mathrm{FOBT}, \quad \boldsymbol{=}$ surgery.

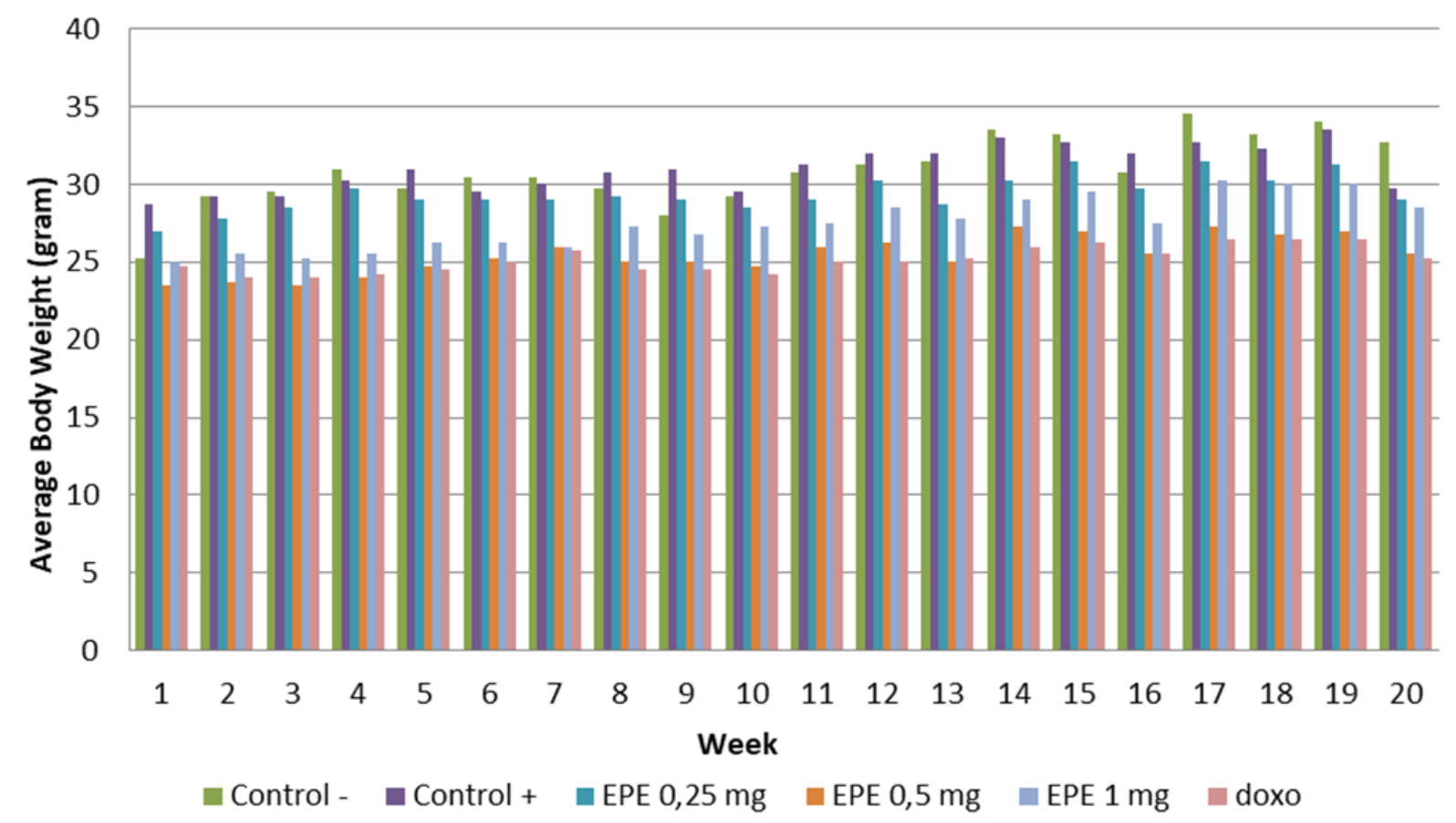

Figure 2. The graph of average body weight in BALB/c mice of the CAC model. (green bar) Negative control, (purple bar) Positive control (blue bar) EPE $0.25 \mathrm{mg} / 20 \mathrm{gBW}$, (orange bar) EPE $0.50 \mathrm{mg} / 20 \mathrm{gBW}$, (grey bar) EPE $1.00 \mathrm{mg} / 20 \mathrm{gBW}$, and (peach bar) Doxorubicin $0.052 \mathrm{mg} / 20 \mathrm{gBW}$. Weight measurement is carried out every week on all mice each group. Bodyweight range from $1^{\text {st }}$ to $20^{\text {th }}$ week was $20-35 \mathrm{~g}$. 


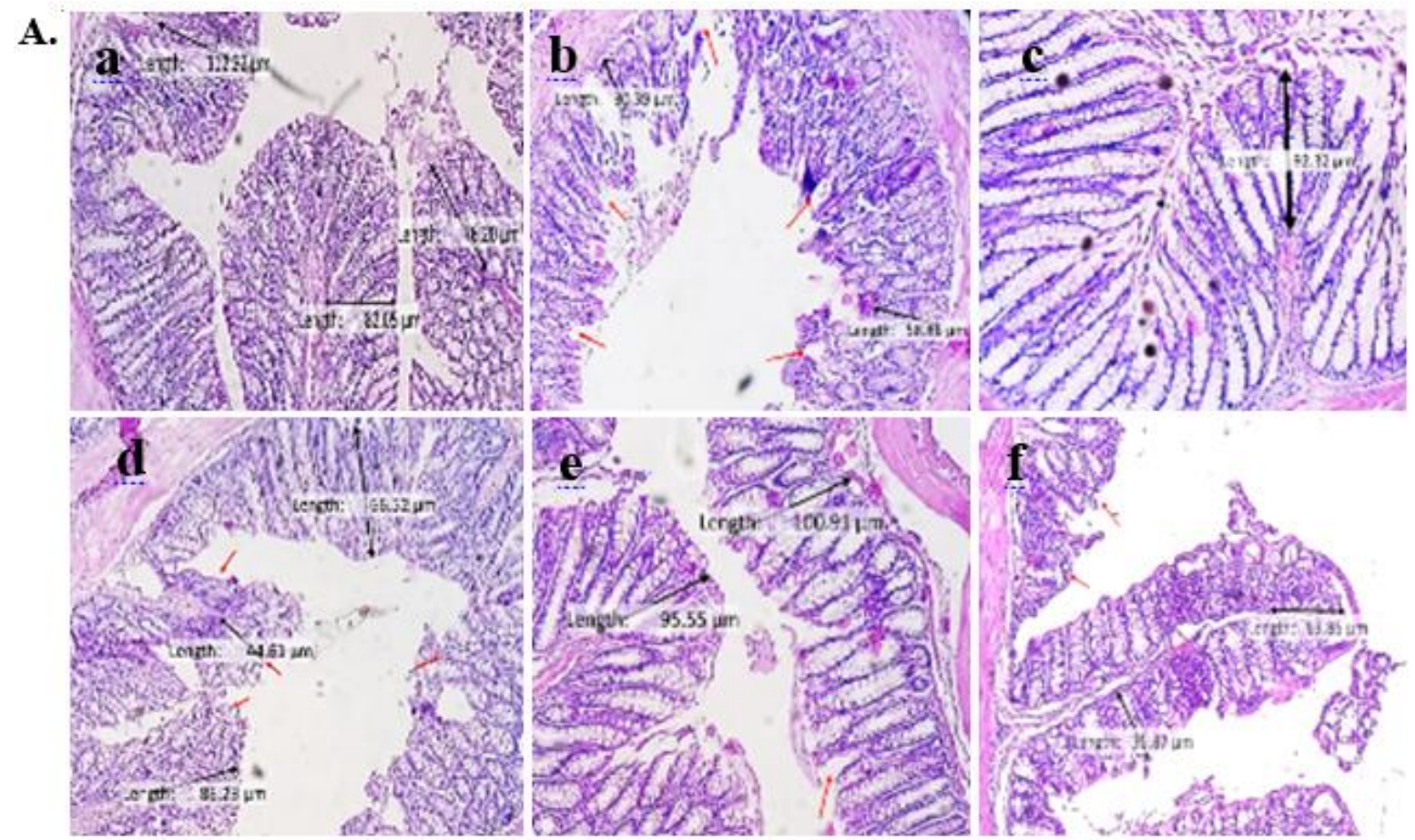

B.

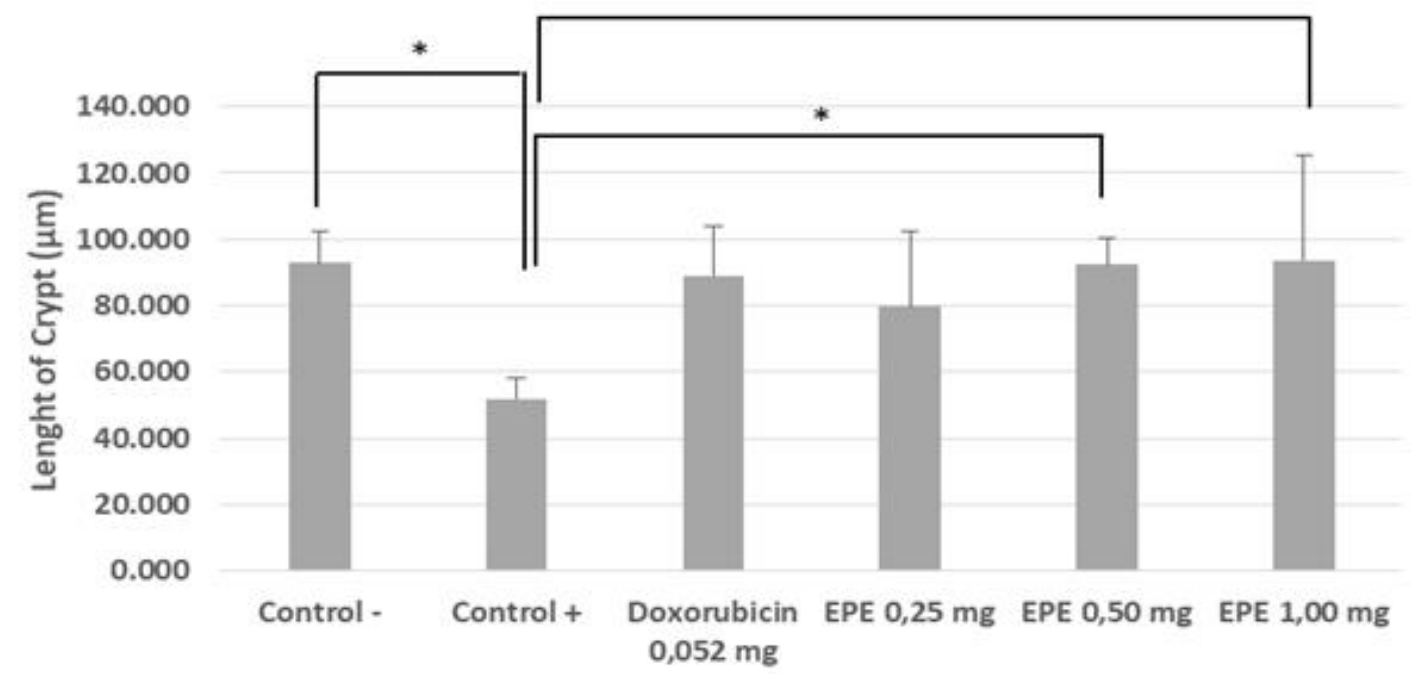

Figure 3. A. Histopathological description of colonic crypt length of the BALB/c mice of colitis-associated colon cancer model after EPE treatment. HE staining. 100x magnification. (a). C- (normal) : normal structures of colon and cryptic; (b). C+ (induction of AOM DSS) : cryptic shortening, severe epithelial damage; (c). Doxorubicin $0.052 \mathrm{mg} / 20 \mathrm{gBW}$ : longitudinal crypts, normal structure of colon; (d). EPE 0.25 mg/20gBW: crypt extends slightly, moderate epithelial damage; (e). EPE $0.50 \mathrm{mg} / 20 \mathrm{gBW}$ : prolonged crypts, mild epithelial damage; (f). EPE $1.00 \mathrm{mg} / 20 \mathrm{gBW}$ : prolonged crypts, mild epithelial damage. Description: $\square=$ cryptic length, $\leftrightarrow=$ epithelial damage, $\rightarrow=$ : inflammatory cell infiltration. B. Graph of crypt length of BALB/c mice of colitis-associated colon cancer model after EPE treatment. Description: *shows the level of significant difference $\mathrm{p}<0.05$ 
A.
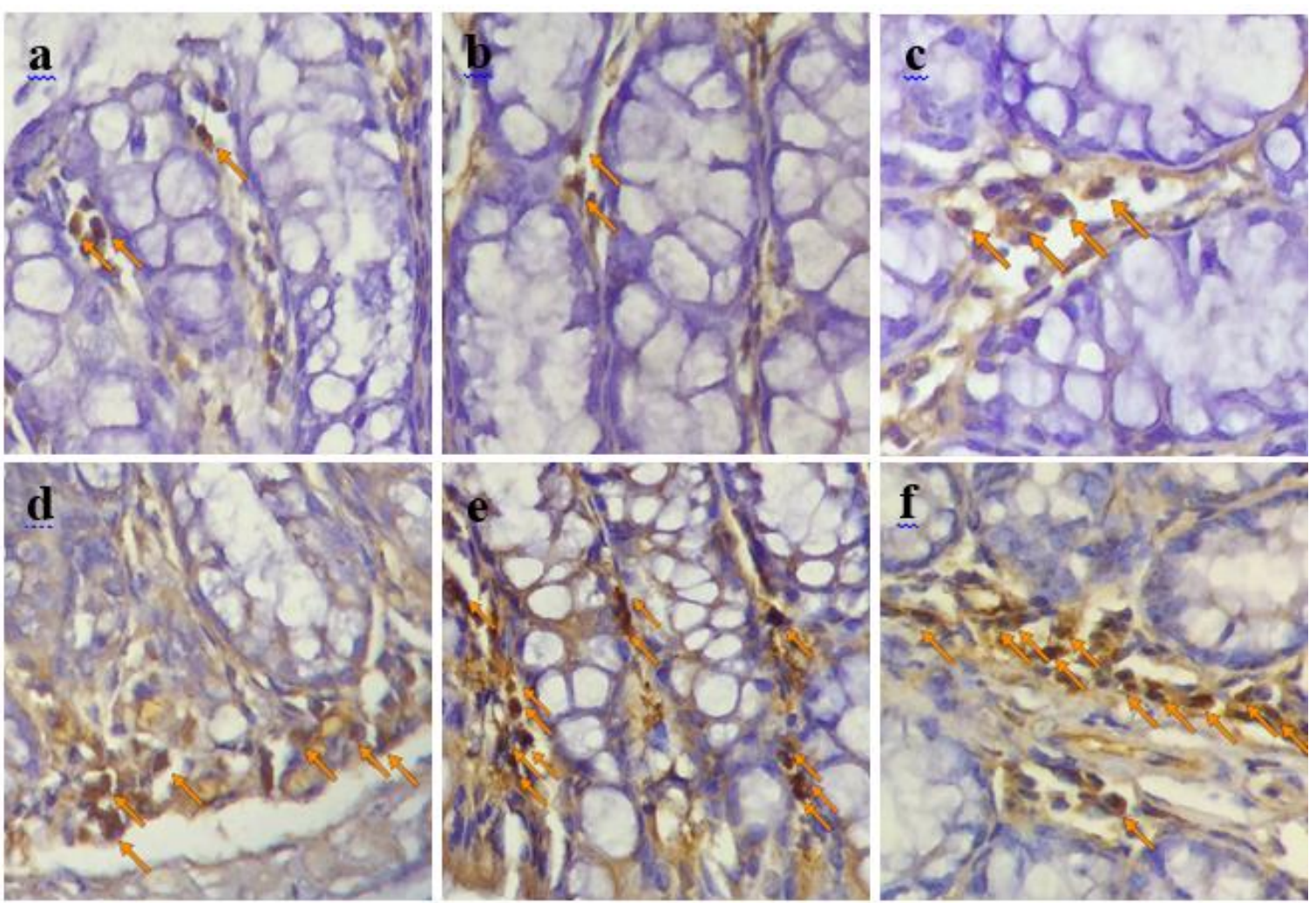

B.

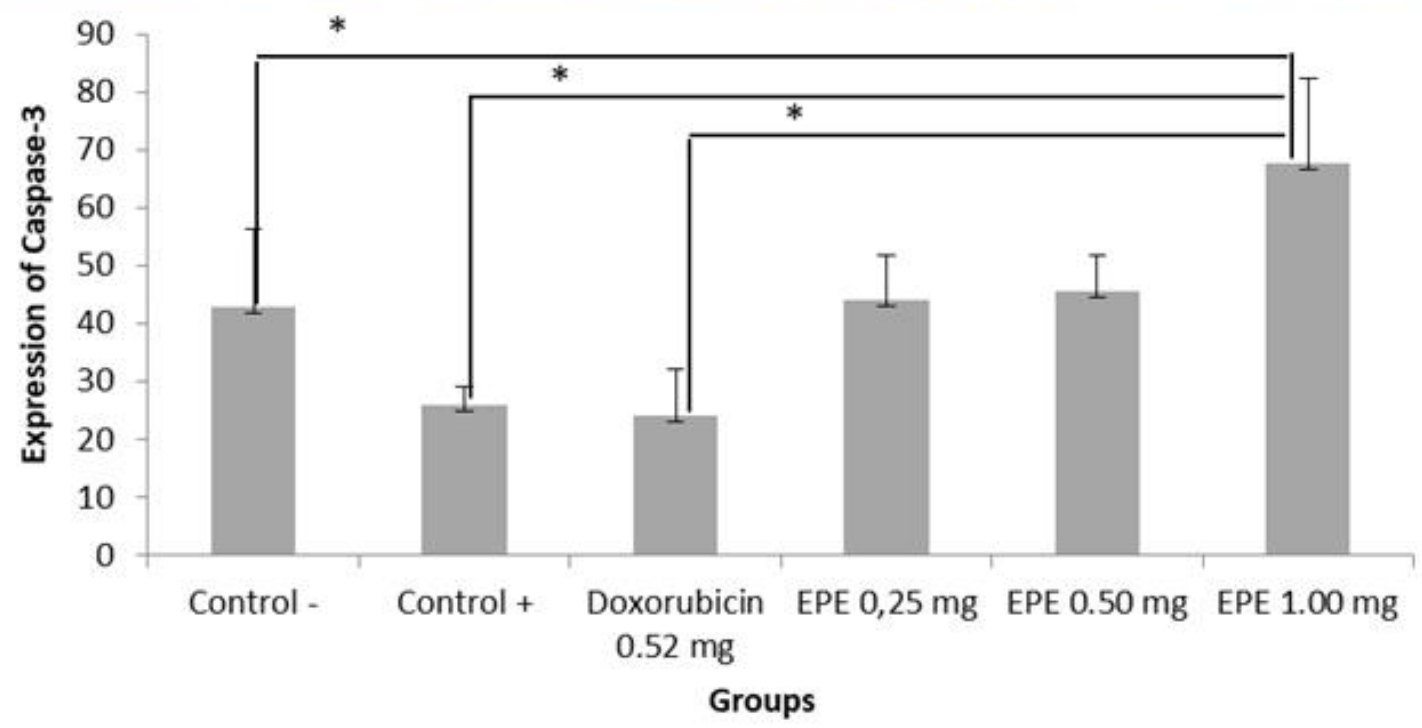

Figure 4. A. Immunohistochemical staining of caspase- 3 expression of murine models of the colon tissue of colitis-associated colon cancer model mice after EPE treatment. 400x magnification. (a) Negative control, (b) Positive control (c) Doxorubicin $0.052 \mathrm{mg} / 20 \mathrm{gBW}$, (d) EPE $0.25 \mathrm{mg} / 20 \mathrm{gBW}$, (e) EPE $0.50 \mathrm{mg} / 20 \mathrm{gBW}$, (f) EPE $1.00 \mathrm{mg} / 20 \mathrm{gBW}$. The arrow indicates the expression of Caspase-3 (apoptosis). B. Graph of caspase3 expression mean data in animal models colon induced with AOM-DSS after EPE therapy. ${ }^{*} \mathrm{p}<0.05$ 
It can be seen in Figure 3.B that the higher the EPE dose is given, the higher the colonic crypt length average of the mouse mice. There are significant differences in the group dose of 0.50 $\mathrm{mg} / 20 \mathrm{gBW}$ and $1.00 \mathrm{mg} / 20 \mathrm{gBW}$ compared to the positive control group. It shows that the administration of EPE affects the crypt elongation and improves the structure of colonic crypts. Previous studies have reported that EPE contains oxyresveratrol and isoliquiritigenin compounds as major compounds (Minggarwati, 2017). Oxyresveratrol can increase the tight junction integrity by activating phosphorylation of protein kinase $\mathrm{C}(\mathrm{PKC})$ so that it induces the activation of the mitogen-activated protein kinase (MAPK) gene. The activation of the MAPK gene after the administration of oxyresveratrol will be followed by an increase in caudal type homeobox 2 (Cdx-2) expression. This expression of $\mathrm{Cdx}-2$ is found in the intestinal epithelial layer, and it will increase the protein expression of the tight junction formation when it increases (Jo et al., 2017).

\section{EPE increases the expression of caspase-3 $\mathrm{BALB} / \mathrm{c}$ mice in the CAC model}

The increase in caspase- 3 expression in BALB/c mice of the CAC model due to EPE treatment was evaluated using the immunohistochemical method. The results of the observations indicate a difference in the mean score of caspase-3 expressions (Table 3). The higher the dose given to experimental animals, the higher the caspase- 3 expression would be. The statistical analysis showed that the EPE group with dose of $1.00 \mathrm{mg} / 20 \mathrm{gBW}$ had a significant difference $(\mathrm{p}<0.05)$ compared to the positive, negative, and doxorubicin group.

Besides being able to repair histopathology in the colon, compounds in EPE are also known to be able to induce apoptosis in cancer cells. Based on Figure 4.A, it can be seen that there are differences in the number of caspase- 3 expressions in all groups treated with EPE. When the higher the concentration of EPE dose given, the higher caspase-3 expression would appear. Statistical analysis also showed that the treatment group with a dose of $1.00 \mathrm{mg} / 20 \mathrm{gBW}$ has a significant difference from the negative control, positive control, and doxorubicin group (Figure 4.B). It indicates that there is an increase in apoptotic activity that occurs in EPE therapy groups.

.The molecular mechanisms process of apoptosis in the EPE therapy groups still cannot indeed be explained. However, the lead compounds in EPE, such as Isoliquiritigenin, Oxyresveratrol, and Naphtoquinone, were assumed to induce apoptosis via two pathways, intrinsic and extrinsic pathways. According to Jin Hao (2018), the increased regulation of p62 induced by isoliquiritigenin can induce apoptosis in cancer cells through the downregulation of caspase- 8 activation. The caspase- 8 activation will induce the mitochondrial membrane so that it can release the proapoptotic molecule named cytochrome-c. The release of cytochrome-c will form a complex bond with APAF-1 and caspase- 9 called apoptosomes. Furthermore, the caspase- 9 will activate the caspase executor, caspase-3 (Sari, 2010). Other studies have also shown that isoliquiritigenin compounds could inhibit the growth of prostate cancer cells by inducing apoptosis through mediating the mitochondrial membrane to release cytochrome-c (Jung, 2006).

\section{CONCLUSION}

Based on the results in this study, the administration of EPE has the potential effect of inhibiting the development of colon cancer in BALB/c mice of colitis-associated colon cancer model. Along with the increase of the dose of 0.25 $\mathrm{mg} / 20 \mathrm{~g} \mathrm{BW} ; 0.50 \mathrm{mg} / 20 \mathrm{~g} \mathrm{BW}$; and $1.00 \mathrm{mg} / 20 \mathrm{~g}$ BW also showed the enhancement of colonic crypts length and caspase-3 expression compared to induction (positive control) group (AOM and DSS only, without EPE).

\section{ACKNOWLEDGEMENT}

The author would like to acknowledge the assistance of this research funds to The Directorate of Islamic Higher Education Ministry of Religious Indonesia through a competitive grant program Science and Technology (Program Hibah Bersaing Sains dan Teknologi; PST) 2015.

\section{REFERENCES}

Ariestine, DA 2008. Ulcerative colitis in terms of aetiological, clinical and pathogenetic aspects. Medan: Faculty of Medicine, University of North Sumatra.

Bahmudah, H. 2008. Anticancer Activity Test of Colon Ethanol Extract Herba Sambiloto (Andrographis paniculata Nees.) In DMBAInduced Mice. Thesis. Faculty of Pharmacy Airlangga University Department of Pharmacognosy and Photochemistry. Surabaya.

Endharti, AT, Wulandari, A., Listiyana, A., Norahmawati, E., and Permana, S. 2016. 
Dendrophthoe pentandra (L.) Miq Extract Effectively Inhibiting Inflammation, Proliferation, and Induces p53 Expression on Colitis Associated Colon Cnacer. Biomed Central Complementary and Alternative Medicine, 16: 374-381.

Erben, U., Loddenkemper, C., Doerfel, K., Speckermann, S., Haller, D., Heimesaat, MM, Zeitz, M., Siegmund, B., Kuhl, AA 2014. A Guide to Histomorphological Evaluation of Intestinal Inflammation in Mouse Models. International Journal of Clinical and Experimental Pathology, 7 (8): 4557-4576.

Hildebrand JS, Jacobs EJ, Campbell PT, McCullough ML, Terrace LR, Thun MJ, et al. 2009. Colorectal cancer incidence and postmenopausal hormone use by type, recency, and duration in cancer prevention study II. Cancer Epidemiol Biomarkers Prav . 18: 2835-41.

Huwaida, IF 2017. Profiling of Anticancer Activity and Toxicity of Dayak Onions (Eleutherine Palmifolia (L.)) Against Widr Colon Cancer Cells and Normal Cells (Vero Cell Line). Thesis. Maulana Malik Ibrahim State Islamic University Malang.

Jin, $\mathrm{H}$ ao ., Et al. 2018. Isoliquiritigenin-Mediated P62 / SQSTM1 Induction Regulates Apoptotic Potential Through Attenuation of Caspase-8 Activation In Colorectal Cancer Cells. European Journal of Pharmacology . Republic of Korea.

Jo, H., Hwang, D., Kim, JK, Lim, YH 2017. Oxyresveratrol Improves Tight Junction Integrity Through the PKC and MAPK Signaling Pathways in Caco-2 Cells. Food and Chemical Toxicology, 108: 203-213.

Jung, IJ, et al. 2006. Isoliquiritigenin induces apoptosis by depolarizing mitochondrial membranes in prostate cancer cells. Journal of Nutritional Biochemistry , 17 (2006) 689696.

Kumar et al. 2010. Pathologic Basic of Disease. 8th Edition . Philadelphia: Elsevier. p. 11311146.

Kumar, V., Abbas, AK, and Aster, JC 2013. Basic Pathology. Philadhelphia: Elsevier Saunders. Thing 587-596; 603-610.
Kuntorini, EM, Dewi, M., and Misrina. 2016. Anatomical Structure and Antioxidant Activity of Red Bulb Plant Eleutherine americana on Different Plant Age. Biodiversity, 17 (1): 229-233.

Minggarwati, T.S 2017. Test for anticancer activity and identification of active compounds from the fraction of tubers of sabrang onions (Eleutherine palmifolia (L.) Merr.) Against HeLa cervical cancer cells . Thesis. Maulana Malik Ibrahim State Islamic University Malang.

Muhartono, and Subeki. 2017. Expression of Caspase-3 in Rat Breast Cancer After Brusein-A Anticancer Application. Global Medical and Health Communication, Vol. 5 No. 3.

Roselyn, AP, et al . 2016. Effect of Taurine Giving on Lung Histopathology Picture of Mice (Mus musculus) Induced by Benzo ( $\alpha$ ) Pirates by In Vivo. Journal of Indonesian Nature 17 (1), 2223.

Sa'adah, H., et al . 2017. Effect of Extraction Methods on Levels of Flavonoid Ethanol Extract of Dayak Onion Bulbs (Eleutherine Palmifolia (L.) Merr) with Spectrophotometric Methods. Borneo Journal Journal of Pharmascientech, Vol. 01, No. 01.

Snider, AJ, et al. 2016. Murine Model for ColitisAssociated Cancer of The Colon. Mouse Models for Drugs Discovery: Methods and Protocols. Methods in Molecular Biology, 1438: 245-254.

Tamaki T, Naomoto Y, Kimura S, Kawshima R, Shirakawa Y, et al. 2003. Apoptosis in Normal Tissue Induced by Anti-Cancer Drugs. J Int Med Res .31: 6-16.

Wicaksono, MHB, Permana, S. 2013 Potential Ethanol Fraction of Mango Parasols (Dendrophthoe pentandra) as Colonic Anticancer Agents in Mice (Mus musculus Balb/c) after Induction of Sodium Dextran Sulfate (DSS) and Azoxymethane (AOM). Journal of Biotropics, (1) 2: 75-81 